\title{
Does Trade Credit Spur Firm Performance? A Case Study in Vietnam
}

Submitted 15/03/20, $1^{\text {st }}$ revision 20/04/19, $2^{\text {nd }}$ revision $25 / 05 / 19$, accepted 20/07/20

\author{
Quoc Viet Pham ${ }^{1}$, Tran Quang Phuc Pham ${ }^{2}$
}

\begin{abstract}
:
Purpose: The paper aims to examine the impacts of trade credit on firm performance in Vietnam, representing a small transition economy with high openness environment.

Design/Methodology/Aproach: Generalized least squares method of estimation was used to test the hypotheses on a sample of 279 companies listed on Ho Chi Minh City Stock Exchange (HOSE) during the 2012-2018 period, after the global financial crisis.

Findings: The research findings support the positive influences of trade credit on firm performance of large businesses through both accounts receivable and trade payables and reversal effects on small business. These results show the advantages of large-scale companies own over the smaller ones in acquiring financing resources and imposing market power on their business partners, which help them optimize the benefits of trade credit.

Practical implications: Research results indicate that corporates should increase their business scale to capitalize on the benefits of trade credit, and small-scale businesses should control the cost of trade credit.

Originality/Value: The paper contributes to the literature in three main ways. Firstly, our exclusive offers new insights into understanding the behavior of Vietnamese firms, and this would give implications for transition economies in the world. Secondly, the study was carried out in the post-crisis period, with regulatory changes in banking management. Thirdly, this research compensates for the lack of empirical evidence in this field of research.
\end{abstract}

Keywords: Trade credit, firm performance, accounts receivable, trade payables.

JEL Codes: G32, C23, C14, L25.

Paper type: Research paper.

${ }^{1}$ Corresponding author. University of Finance-Marketing, Viet Nam.

E-mail:vietpq@ufm.edu.vn

${ }^{2}$ Thien Nghi Ltd. Co., Viet Nam.E-mail: ptqphuc@gmail.com 


\section{Introduction}

Trade credit plays an important role in financing firms' operation (Mian and Smith Jr (1992), and Mian and Smith Jr (1994)), especially, when firms face issues of bank credit-constrained (Petersen and Rajan, 1994a; 1994b; 1997), and engage in emerging markets with underdeveloped legal systems and capital markets (Demirgüç-Kunt and Maksimovic, 2001; Fisman and Love 2003).

The economic literature gives three explanations of why trade credit boosts firm performance. First, as an important form of financing (Emery, 1987), especially in developing economies, trade credit plays a complement role to formal financing, such as bank loans (Allen, Qian, and Qian, 2005; Ayyagari, Demirgüç-Kunt, and Maksimovic, 2010)). Several previous studies (Casey and O'Toole, 2014; Carbo-Valverde, Rodriguez-Fernandez, and Udell, 2009; 2016; Garcia-Appendini and Montoriol-Garriga, 2013; Ferrando and Mulier, 2013; Petersen and Rajan, 1997) find evidence that trade credit provides an effective buffer for firms in removing financial constraint. Second, Fisman (2001) argues that suppliers' trade credit can lessen firms' input shortages, and thus their operation is more smoothly and efficient. Third, as argued by Long, Malitz, and Ravid (1993), product quality can be enhanced through improvements of input quality which is conditioned by trade credit.

From the perspective of management, trade credit may affect firm performance through some channels. First, from the perspective of management, trade credit management is a crucial component of working capital policy and corporate strategy (Sartoris and Hill, 1983). Thus, the extension of trade credit to financially constrained customers may strengthen firms' operations relative to their industry competitors (horizontal competition). Second, from the perspective of supply chain finance, trade credit has long been recognized to play an important part in vertical completion (Lee, Zhou, and Wang, 2018). Suppliers with weak market power in their product market may employ trade credit as a competitive tool and provide more trade credit in supply chains (Dass, Kale, and Nanda, 2015; Fabbri and Klapper, 2008; Van Horen, 2005). On the other hand, strong buyers may demand long-term conditions of payment from their suppliers (Klapper, Laeven, and Rajan, 2012). Both suppliers and buyers can mutually benefit from enhancing such collaboration (e.g., sharing demand or inventory accumulation) in supply chains (Kulp, 2002; Cachon and Fisher, 2000).

Among the impacting factors on firm performance, financing has been proved to play a vital role, both theoretically and empirically. Trade credit is a source of financing that is indispensable to businesses, even under perfect competition (Brennan, Maksimovics, aand Zechner, 1988). Trade credit refers to a business agreement, in which the supplier allows a customer to pay at a later scheduled date under certain conditions. Trade credit is crucial to businesses on a tight or limited budget (Hoang, Xiao, and Akbar, 2019). However, the cost of trade credit is 
immense (Cunat, 2007). If used properly, trade credit will be beneficial for business activities. However, it is still unclear the causal effect of trade credit on firm performance.

Research on trade credit mainly focuses on its components, but findings on the effects of trade credit on firm profitability and value are scarce (Martínez-Sola, García-Teruel, and Martínez-Solano, 2014). To the authors' knowledge, Kestens, Van Cauwenberge, and Bauwhede (2012), Martínez-Sola et al. (2014), and Abuhommous (2017) are the first authors to study this topic; however, there is yet to be study in transition economies. In Vietnam, a prime example of transition economies, trade credit is not widely used, on average less than $20 \%$ of total assets (see Table 2), in comparison with $25 \%$ of companies' total assets in Europe (Giannetti, 2003). The paper contributes to the literature in three main ways. Firstly, our exclusive focus on firm-level data for Vietnam offers new insights into understanding the behavior and performance of Vietnamese firms, and this would give implications for transition economies in the world. Secondly, the study was carried out in the post-crisis and economic growth restoration period in Vietnam, with regulatory changes to enhance bank management safety which potentially affects bank credit and trade credit. Thirdly, this research investigates the impacts of trade credit, through accounts receivable and trade payables, on firm performance, to compensate for the lack of empirical evidence in this field of research, so far.

Our hypotheses are: (1) Accounts receivable positively affect firm performance of companies in Vietnam, especially large-scale businesses; and (2) Trade payables affect firm performance of companies in Vietnam, in particular positively to large businesses and negatively to small businesses. The dataset is a balanced panel comprising of 279 companies in 7 years, from 2012 to 2018 (resulting in a total of 1.953 observations) from 279 companies listed on Ho Chi Minh City Stock Exchange. The main research findings, by applying generalized least squares method of estimation, include: (1) Accounts receivable affect firm performance negatively, including small-scale businesses, but positively the performance of large-scale businesses; (2) Trade payables affect firm performance positively, including largescale businesses, but their impacts on performance of small-scale businesses, despite negative, remain ambiguous. Research results indicate that corporates should expand their business to capitalize on the benefits of trade credit. Furthermore, small-scale businesses should be cautious with trade credit management to increase benefits and they should control the costs of trade credit.

The remainder of the paper is structured as follows: Section 2 discusses the theoretical background and empirical evidence. Hypothesis, research models and data are presented in Section 3. Section 4 presents the results and further discussions. Section 5 summarizes the results and policy implications.

\section{Theoretical Background and Empirical Evidence}


Mian and Smith Jr (1992) suggest that trade credit is an agreement between seller and buyer, in which the seller accepts delayed payment for their products instead of cash payment. According to Hillier, Ross, Westerfield, Jaffe, and Jordan (2013), from an accounting standpoint, trade credit is a type of credit extended by one company to another, entailing accounts receivable.

\subsection{Theoretical Background}

Models on roles of trade credit have been developed over the years. Meltzer (1960) considers trade credit as a bank credit redistribution tool, by which healthy companies utilize bank credit to provide trade credit to companies with limited credit. Schwartz (1974) establishes an economic model of trade credit as an integral part of a seller's pricing policy. He proves that trade credit is offered by firms with better access to the capital market to companies under financial constraints but also growth opportunities. Ferris (1981) considered trade credit as a tool to separate a single cash sales transaction (goods in exchange for money) into two transactions (goods in exchange for credit, credit in exchange for money). Through this mechanism, cash flow uncertainty is reduced and thus the sellers can reduce their cash holdings and manage cash more efficiently.

Brennan et al. (1988) proposed that even in the perfectly competitive banking industry, companies with market power are still capable of offering trade credit if credit customers have lower reservation prices than cash customers, or in the case of adverse selection. It is hypothesized that in the case of adverse selection or lack of competition in the commodity market, suppliers benefit from price discrimination (between cash and credit customers). Mian and Smith Jr (1992) summarized the incentives to offer trade credit, including cost advantages (collateral value of the buyer, low credit ratings costs, lower cash flow management cost), market power (through price discrimination by combining output price with credit terms), tax (delayed payments lead to a drop in the real value of tax payments).

Petersen and Rajan (1997) argue that small businesses with limited access to capital markets tend to use trade credit. On the other hand, firms offer trade credit to their customers who are under financial constraints because they have more advantages in data collection, liquid assets, and hidden benefits in buyers. The authors conclude that trade credit brings about financing benefits (through data collection cost, management cost and collateral assets value of the buyer), generates profits through price discrimination, cuts transaction costs by separating the time of delivery and the time of payment (in which inventory costs and inventory financing are reduced).

Cunat (2007) states that even though trade credit has a much higher hidden interest in comparison with bank credit, trade credit will continue to thrive and remains an essential source of financing. Accordingly, there are two fundamental motives for trade credit: (1) suppliers can collect debts more easily than banks because they have 
the right to stop the supply to customers; (2) suppliers provide liquidity financing for their customers in case of temporary liquidity shocks.

\subsection{Empirical Evidence}

Researches on trade credit have been conducted in three main areas: (1) impacting factors on trade credit, (2) the relationship between trade credit and bank credit, and (3) effects of trade credit on firm performance. Factors impacting trade credit are empirically proven to be firm size, business age, cash flow, and firm performance, solvency, tangible assets (Huyghebaert, 2006; García-Teruel and Martinez-Solano, 2010), financial distress (Molina and Preve, 2009). In addition, the relationship between trade credit and bank credit has been verified to involve the complementary relationship between bank credit and accounts payable, and on the other hand, the substitute relationship between bank and trade payables, especially a palpable substitute relationship in crisis periods (Preve, Love, and Sarria-Allende 2005; Love and Zaidi, 2010).

Unlike a rather plenty of studies done in the two above directions, research on the impacts of trade credit on firm performance remains scarce, except for the works of Kestens et al. (2012), Martínez-Sola et al. (2014), Abuhommous (2017), Lee et al. (2018), and Hoang et al. (2019). Kestens et al. (2012) are the pioneers in the research of the relationship between trade credit and firm performance, using data collected from 15.440 non-financial corporations in Belgium from the years 2006 to 2009. Findings supported a positive relationship between accounts receivable and firm performance, as well as a negative relationship between trade payables and firm performance.

Martínez-Sola et al. (2014) carry on the research by determining the correlation between trade credit (through accounts receivable) and profitability of SMEs in Iberia (including Portugal and Spain). The authors apply the data from 11.337 SMEs in the 2000-2007 period to find, by regression analysis, the impacts of accounts receivable on profitability. The results demonstrate that accounts receivable enhances the profitability of SMEs. Abuhommous (2017) proposes that the impacts of trade credit on firm performance are subject to a company's traits, namely firm size, liquidity, and revenue fluctuations. The author uses the data of Jordanian companies in the 1995-2015 period and presents findings on the positive influence of accounts receivable on firm performance; large-scale financially stable businesses with high revenue fluctuations use accounts receivable to extend profits. Lee et al. (2018) examine trade credit in competitive environments which impacts firm's performance to investigate the collaboration and competition effects of trade credit.

Through the Compustat data in the 1976-2010 period, the authors conclude the positive relationship between industry-average trade credit and firm performance for both buyers and sellers. Nonetheless, abnormal trade payables curb firm performance, while abnormal accounts receivable, by contrast, boost firm 
performance. Hoang et al. (2019) scrutinize the non-linear relationship between trade credit and profitability of East Asia and Pacific SMEs under the financial constraints. The authors gather SME data of 9 East Asian and Southeast Asian countries in the 2010-2016 period to justify the hypothesis. The authors discover the non-linear inverted-U shaped between accounts receivable/trade payables and profitability, accounting for the trade credit optimum. Besides, the trade credit optimum for companies under financial constraints is lower than that of companies without financial constraints.

Unlike previous studies, an empirical study about the effects of trade credit on a firm's profitability conducted in Vietnam, the prime example for a transition economy with perfect financial markets, is expected to compensate for the lack of empirical literature on this topic. On top of that, a study carried out in the post-crisis and economic growth restoration period, with regulatory changes to enhance bank management safety may capture the potential effects of bank credit and trade credit. Last but not least, a research investigates the impacts of trade credit, through accounts receivable and trade payables, on firm performance, will contribute to fill the gap of empirical evidence in, so far.

\section{Research Methodology and Data}

\subsection{Hypothesis Development}

All hypotheses explaining the benefits of trade credit in the literature all support the positive correlation between accounts receivable and firm performance Meltzer (1960), Schwartz (1974), and Ferris (1981) as the most distinguished authors. Mian and Smith Jr., (1992) and Petersen and Rajan (1997) all emphasize market power, cost advantage and price discrimination as the keys to how trade credit can boost firm performance. Empirical evidence of various business environments Kestens et al. (2012), Martínez-Sola et al. (2014), Lee et al. (2018), and Abuhommous (2017) support these arguments. In Vietnam, Pham Quoc Viet and Nguyen Huu Duy (2017) found evidence of the complementary relationship between bank credit and trade credit, which suggests that firms use trade credit to reallocate funding to expand market share. Therefore, it is hypothesized that:

$H_{1}$ : Accounts receivable positively affect firm performance of companies in Vietnam, especially large-scale businesses.

Scholars suppose that companies under financial constraints tend to utilize trade credit through trade payables to healthy companies in the supply chain (Meltzer, 1960; Schwartz, 1974; Petersen and Rajan, 1997). Cunat (2007) also claimed that accepting trade payables helps companies avoid temporary liquidity shocks, even though trade credit has higher hidden interests than bank credit. Besides, in crisis periods, trade credit acts as a substitute for bank credit (Preve et al. 2005; Love and Zaidi (2010). Nevertheless, empirical evidence has remained inconsistent while 
Kestens et al. (2012) discover a negative relationship between trade payables and firm performance. Lee et al. (2018) find a positive correlation between these two variables (except for abnormal trade payables); Hoang et al. (2019) identify a nonlinear inverted-U shaped between trade payables and firm performance. From our perspective, the main reason for this discrepancy in empirical evidence is the unequal benefits from trade payables and the costs that companies have to pay for trade credit. Large-scale businesses with market power may benefit from trade payables, while it is the opposite for small businesses. Thus, it is hypothesized that:

$\mathrm{H}_{2}$ : Trade payables affect firm performance of companies in Vietnam, in particular positively for large businesses and negatively for small businesses.

\subsection{Model Specification}

Based on the research of Martínez-Sola et al. (2014), with the addition of trade payables as a measurement, Kestens et al. (2012) propose the two following models:

$$
\begin{aligned}
& R O A_{i t}=\beta_{1}+\beta_{2} T C R_{i t}+\beta_{3} S I Z E_{i t}+\beta_{4} G R O W T H_{i t}+\beta_{5} D E B T_{i t}+\beta_{6} G D P_{t}+\varepsilon_{i t} \text { (1) } \\
& R O A_{i t}=\beta_{1}+\beta_{2} T C P_{i t}+\beta_{3} S I Z E_{i t}+\beta_{4} G R O W T H_{i t}+\beta_{5} D E B T_{i t}+\beta_{6} G D P_{t}+\varepsilon_{i t} \text { (2) }
\end{aligned}
$$

The first regression equation (1) with the independent variable TCP (accounts receivable) tests the first hypothesis, while the second regression equation (2) with the independent variable TCP (trade payables) tests the second hypothesis. The dependent variable, ROA, is determined by dividing EBIT by total assets based on research by Martínez-Sola et al. (2014), Abuhommous (2017), and Hoang et al. (2019)) as displayed in Table 1.

\begin{tabular}{|c|c|c|}
\hline ABBREVIATIONS & VARIABLES & DETERMINATION \\
\hline ROA & FIRM PERFORMANCE & $\begin{array}{l}\text { ThE Ratio OF Earnings Before InTEREST AND } \\
\text { TAXES To Total AsSETS }\end{array}$ \\
\hline TCP & TRADE PAyABLES & 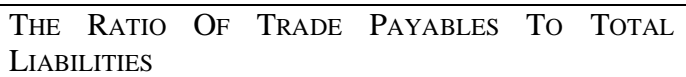 \\
\hline TCR & ACCOUNTS RECEIVABLE & $\begin{array}{l}\text { The Ratio Of Accounts Receivable To Total } \\
\text { Assets }\end{array}$ \\
\hline SIZE & FIRM SIZE & THE NATURAL LOGARITHM OF TOTAL AsSETS \\
\hline GROWTH & GROWTH OPPORTUNITIES & $\left(\right.$ SALES $\left._{\mathrm{T}}-\mathrm{SALES}_{\mathrm{T}-1}\right) / \mathrm{SALES}_{\mathrm{T}-1}$ \\
\hline DEBT & LEVERAGE & THE RATIO OF DEBT To TOTAL ASSETS \\
\hline GDP & $\begin{array}{l}\text { THE ANNUAL } \\
\text { GROWTH RATE }\end{array}$ & $\left(\mathrm{GDP}_{\mathrm{T}}-\mathrm{GDP}_{\mathrm{T}-1}\right) / \mathrm{GDP}_{\mathrm{T}}$ \\
\hline
\end{tabular}

Table 1. Definition of variables in the model

Source: Authors.

The two main independent variables in the models are respectively TCR and TCP, in which TCR is determined by dividing accounts receivable by total assets and TCP is determined by dividing trade payables by total liabilities as employed by several 
scholars such (Kestens et al., 2012; Martínez-Sola et al., 2014; Abuhommous, 2017; Hoang et al., 2019) as presented in Table 1. Controlled variables for profitability in Table 1, as derived from the findings by Deloof (2003), and Martínez-Sola et al. (2014), include firm size (SIZE), growth opportunities (GROWTH), debt ratio (DEBT), and GDP growth (GDP).

OLS-Regression, Fixed Effect Method (FEM) and Random Effect Method (REM) are used for the obtained data. An efficient estimator is then chosen using Hausman's (1978)'s specification test. Modified Wald test and Wooldridge test are then respectively employed to test for heteroscedasticity and serial correlation, and according to Hoang et al. (2019), generalized least squares (GLS) method may be used to solve these problems.

\subsection{Data Source}

Data used in this research was collected from audited financial statements of companies listed on Ho Chi Minh City Stock Exchange (HOSE) from the year 2012 to 2018. Furthermore, sales data was collected from the year 2011 for calculation of annual firm growth rate. The annual GDP growth rate was from the World Bank. Corporates were chosen by the criteria set by Martínez-Sola et al. (2014), which means that companies in the finance sector and the rest of the companies did not have adequate data for the research process. Data sample is a balanced panel comprising 279 companies in 7 years, from 2012 to 2018 , making a total of 1.953 observations.

Data was sampled for the population and two subsamples following the median of the scale of the population. The scale was chosen as a category to determine subsample because size is also a category to determine financial constraints, in addition to dividend payout ratio, bond ratings, commercial paper ratings, and $\mathrm{KZ}$ index (according to Almeida, Campello, and Weisbach, 2004). Moreover, large businesses have more market power and, therefore, can impose trade conditions on their partners (Brennan et al., 1988; Mian and Smith Jr., 1992) and benefit from trade credit.

\section{Research Results}

Table 2 shows that average firm performance amounts to $9.69 \% / y e a r$, average accounts receivable $14.48 \%$ /year and average trade payables $19.41 \%$ /year of total assets, average total assets amount to 1.40 thousand billion VND $\left(\mathrm{e}^{27.97}\right)$, the average revenue growth rate is relatively high, accounting for $21.74 \% / y e a r ;$ meanwhile, the debt ratio is $48.45 \%$ of total assets.

Hausman specification test indicates that the FEM estimator is efficient. Modified Wald test and Wooldridge test imply the problems of heteroscedasticity and serial correlation. We use GLS regression to solve these problems. 
Table 2. Descriptive statistics of the variables

\begin{tabular}{|l|l|l|l|l|l|}
\hline Variables & Observations & Mean & Std. Dev. & Min & Max \\
\hline ROA & 1,953 & 0.096925 & 0.104884 & -1.56811 & 0.997023 \\
\hline TCR & 1,953 & 0.144775 & 0.123268 & 0 & 0.789704 \\
\hline TCP & 1,953 & 0.194143 & 0.172561 & 0 & 0.970374 \\
\hline SIZE & 1,953 & 27.97428 & 1.277781 & 25.33168 & 33.29389 \\
\hline GROWTH & 1,953 & 0.217411 & 1.431069 & -24.1617 & 29.55586 \\
\hline DEBT & 1,953 & 0.484461 & 0.211846 & 0.001981 & 0.992909 \\
\hline GDP & 1,953 & 0.062044 & 0.006473 & 0.052474 & 0.070758 \\
\hline
\end{tabular}

Note: $R O A$ - return on assets; TCR - the ratio of accounts receivable to total assets; TCP the ratio of trade payables to total liabilities; SIZE - the natural logarithm of total assets; GROWTH - sales annual growth; DEBT - the ratio of debt to total assets; GDP - the annual GDP growth.

Source: Research data and calculations by the authors.

Regression results GLS in Table 3 demonstrate the impacts of accounts receivable on firm performance, in particular, negative impacts on population and small-scale businesses sample set and positive impacts on large-scale businesses sample set. These results, except for the large-scale businesses sample set, are contrary to expectations and previous empirical evidence by Kestens et al. (2012) and MartínezSola et al. (2014), which indicates a positive relationship. Results for large-scale businesses sample set support the hypotheses on trade credit benefits proposed by Meltzer (1960), Schwartz (1974), Ferris (1981), Mian and Smith Jr (1992) and Petersen and Rajan (1997), as well as results from the empirical studies by Kestens et al. (2012), Martínez-Sola et al. (2014), Lee et al. (2018), and Abuhommous (2017). Large-scale businesses make use of their market advantage to impose trade conditions on buyers. Additionally, access to official funding at low costs allows large corporates to offer their customers trade credit, thus helping them benefit from offering trade credit.

Results for small-scale business sample sets may be explained by limited access to financing, as well as weaker market standing leading to difficulties in imposing trade conditions on customers. Hence, benefits less from offering trade credit are lower than financing costs. Apart from the independent variables, controlled variables also affect firm performance, such as firm size (positive, except for large-scale businesses), growth opportunities (only positive to small-scale businesses), debt ratio (negative), GDP growth (negative, except for large-scale businesses).

Regression results GLS in Table 4 demonstrate the impacts of trade payables on firm performance, in particular, positive impacts on population and large-scale businesses sample set, and negative impacts on small-scale businesses sample set, but these impacts are statistically insignificant. The research yields result that is consistent with expectations. These research results, despite contrary to empirical evidence by Kestens et al. (2012), are in line with those by Lee et al. (2018) and Hoang et al. (2019). 
Table 3. Regression results: Accounts reiceivable in firm performance

\begin{tabular}{|c|c|c|c|c|c|c|c|c|c|}
\hline \multirow{2}{*}{ Variables } & \multicolumn{3}{|l|}{ OLS } & \multicolumn{3}{|l|}{ FEM } & \multicolumn{3}{|l|}{ GLS } \\
\hline & (1) & (1a) & (1b) & (1) & (1a) & (1b) & (1) & (1a) & (1b) \\
\hline \multirow[t]{2}{*}{ TCR } & $\begin{array}{l}-0.0367 \\
* *\end{array}$ & $\begin{array}{l}-0.0887 \\
* * *\end{array}$ & $\begin{array}{l}0.0513 \\
* *\end{array}$ & $\begin{array}{l}0.0570 \\
* *\end{array}$ & $\begin{array}{l}0.1376 \\
* * *\end{array}$ & 0.0523 & $\begin{array}{l}-0.0175 \\
* * *\end{array}$ & $\begin{array}{l}-0.0473 \\
* * *\end{array}$ & $\begin{array}{l}0.0576 \\
* * *\end{array}$ \\
\hline & {$[-1.97]$} & {$[-3.15]$} & [2.24] & {$[2.1]$} & [3.35] & {$[1.44]$} & {$[-2.98]$} & {$[-5.86]$} & {$[5.28]$} \\
\hline \multirow[t]{2}{*}{ SIZE } & $\begin{array}{l}0.0038 \\
* *\end{array}$ & 0.0118 & $\begin{array}{l}0.0065 \\
* * *\end{array}$ & $\begin{array}{l}0.0152 \\
* * *\end{array}$ & $\begin{array}{l}0.0381 \\
* * *\end{array}$ & $\begin{array}{l}-0.0124 \\
*\end{array}$ & $\begin{array}{l}0.0032 \\
* * *\end{array}$ & $\begin{array}{l}0.0113 \\
* * *\end{array}$ & -0.0005 \\
\hline & {$[2.00]$} & [1.72] & [2.63] & {$[2.71]$} & [3.33] & {$[-1.69]$} & [4.48] & [5.27] & {$[-0.32]$} \\
\hline \multirow{2}{*}{ GROWTH } & -0.001 & $\begin{array}{l}0.0140 \\
* *\end{array}$ & $\begin{array}{l}-0.0021 \\
*\end{array}$ & 0.0016 & $\begin{array}{l}0.0212 \\
* * *\end{array}$ & -0.0004 & 0.0006 & $\begin{array}{l}0.0149 \\
* * *\end{array}$ & 0.0002 \\
\hline & {$[-0.63]$} & [2.12] & {$[-1.73]$} & [1.33] & [4.53] & {$[-0.39]$} & {$[0.63]$} & [5.29] & {$[0.31]$} \\
\hline \multirow{2}{*}{ DEBT } & $\begin{array}{l}-0.1887 \\
* * *\end{array}$ & $\begin{array}{l}-0.199 \\
* * *\end{array}$ & $\begin{array}{l}0.181 \\
* * *\end{array}$ & $\begin{array}{l}-0.1850 \\
* * *\end{array}$ & $\begin{array}{l}-0.2505 \\
\text { *** }\end{array}$ & $\begin{array}{l}-0.1851 \\
* * *\end{array}$ & $\begin{array}{l}-0.1728 \\
* * *\end{array}$ & $\begin{array}{l}-0.1810 \\
* * *\end{array}$ & $\begin{array}{l}-0.1927 \\
* * *\end{array}$ \\
\hline & {$[-16.75]$} & {$[-10.4]$} & {$[-14.43]$} & {$[-9.02]$} & {$[-7.76]$} & {$[-6.89]$} & [-39.49] & {$[-28.44]$} & {$[-22.31]$} \\
\hline \multirow{2}{*}{ GDP } & $\begin{array}{l}-0.6606 \\
*\end{array}$ & $\begin{array}{l}-1.215 \\
* *\end{array}$ & -0.4048 & $\begin{array}{l}-1.0209 \\
* * *\end{array}$ & $\begin{array}{l}-1.2255 \\
* *\end{array}$ & -0.0316 & $\begin{array}{l}-0.2818 \\
* *\end{array}$ & $\begin{array}{l}-0.7524 \\
* * *\end{array}$ & -0.1206 \\
\hline & {$[-1.91]$} & {$[-2.03]$} & {$[-1.09]$} & {$[-3.43]$} & {$[-2.57]$} & {$[-0.08]$} & {$[-2.4]$} & {$[-4.39]$} & {$[-0.79]$} \\
\hline \multirow{2}{*}{ _cons } & $0.1284 * *$ & -0.040 & 0.0185 & -0.1839 & $\begin{array}{l}-0.7650 \\
* * * *\end{array}$ & $\begin{array}{l}0.5435 \\
* * *\end{array}$ & $\begin{array}{l}0.1108 \\
* * *\end{array}$ & -0.0708 & $\begin{array}{l}0.2084 \\
* * *\end{array}$ \\
\hline & [2.43] & {$[-0.23]$} & {$[0.26]$} & {$[-1.27]$} & {$[-2.65]$} & [2.78] & [5.66] & {$[-1.34]$} & [4.88] \\
\hline
\end{tabular}

Note: TCR - the ratio of accounts receivable to total assets; SIZE - the natural logarithm of total assets; GROWTH - sales annual growth; DEBT - the ratio of debt to total assets; GDP - the annual GDP growth. Columns (1), (1a), (1b) respectively represent the results of a regression equation (1) for the whole sample, for small-scale businesses sample set and large-scale businesses sample set. ***, **, * correspond to significance levels $1 \%, 5 \%$ and $10 \%$. Numbers in square brackets indicate $t$-values.

Source: The authors' estimation.

Table 4. Regression results: Trade paybles on firm performance

\begin{tabular}{|c|c|c|c|c|c|c|c|c|c|}
\hline \multirow{2}{*}{ Variables } & \multicolumn{3}{|c|}{ POOLED-OLS } & \multicolumn{3}{|l|}{ FEM } & \multicolumn{3}{|l|}{ GLS } \\
\hline & (2) & (2a) & (2b) & (2) & (2a) & (2b) & (2) & (2a) & (2b) \\
\hline \multirow{2}{*}{ TCP } & $\begin{array}{l}0.0369 \\
* * *\end{array}$ & -0.0030 & $\begin{array}{l}0.0859 \\
\text { *** }\end{array}$ & 0.0143 & 0.0197 & 0.02868 & $\begin{array}{l}0.0223 \\
* * *\end{array}$ & -0.0024 & $\begin{array}{l}0.0320 \\
* * *\end{array}$ \\
\hline & [2.84] & {$[-0.15]$} & {$[5.74]$} & [0.83] & [0.83] & [1.05] & [5.17] & {$[-0.38]$} & [4.09] \\
\hline \multirow{2}{*}{ SIZE } & 0.0057 & 0.0122 & 0.0062 & 0.0137 & 0.0364 & $\begin{array}{l}-0.0124 \\
*\end{array}$ & 0.0041 & 0.0127 & -0.0009 \\
\hline & [3.02] & {$[1.75]$} & {$[2.61]$} & [2.47] & [3.16] & {$[-1.67]$} & [5.58] & [5.17] & {$[-0.59]$} \\
\hline \multirow{2}{*}{ GROWTH } & -0.0009 & 0.0150 & & 0.0015 & 0.0204 & -0.0004 & 0.0002 & 0.0136 & 0.0002 \\
\hline & {$[-0.58]$} & [2.26] & {$[-1.6]$} & [1.28] & [4.27] & {$[-0.41]$} & {$[0.16]$} & [5.23] & {$[0.3]$} \\
\hline \multirow{3}{*}{ DEBT } & -0.1931 & -0.2121 & -0.177 & -0.1815 & -0.2435 & -0.1816 & -0.1773 & -0.1965 & -0.1917 \\
\hline & $* * *$ & $* * *$ & $* * *$ & $* * *$ & $* * *$ & $* * *$ & $* * *$ & $* * *$ & $* * *$ \\
\hline & {$[-17.59]$} & {$[-11.33]$} & {$[-14.5]$} & {$[-8.81]$} & {$[-7.49]$} & {$[-6.71]$} & {$[-39.54]$} & {$[-31.8]$} & {$[-20.54]$} \\
\hline \multirow[b]{2}{*}{ GDP } & -0.7616 & -1.3157 & -0.414 & -0.9592 & -1.1640 & -0.0153 & -0.4173 & -0.9106 & -0.0247 \\
\hline & $\begin{array}{l}* * \\
{[-2,21]}\end{array}$ & $\begin{array}{l}* * \\
{[-2,18]}\end{array}$ & [-1.13] & $\begin{array}{l}* * * \\
{[-3.23]}\end{array}$ & $\begin{array}{l}* * \\
{[-2,41]}\end{array}$ & & $* * *$ & $\begin{array}{l}* * * \\
{[-5-42]}\end{array}$ & \\
\hline \multirow{3}{*}{ _cons } & 00723 & 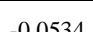 & 00178 & 01433 & -0.7092 & 0.5411 & 0.0889 & 0 & 0.2150 \\
\hline & 0.0725 & -0.0534 & 0.0170 & -0.1435 & & $* * *$ & $* * *$ & -0.0991 & $* * *$ \\
\hline & [1.38] & {$[-0.3]$} & {$[0.26]$} & {$[-0.99]$} & {$[-2.44]$} & {$[2.75]$} & [4.33] & {$[-1.56]$} & {$[5.00]$} \\
\hline
\end{tabular}

Note: TCP - the ratio of trade payables to total liabilities; SIZE - the natural logarithm of total assets; GROWTH - sales annual growth; DEBT - the ratio of debt to total assets; GDP - the annual GDP growth. Columns (2), (2a), (2b) respectively represent the results of a regression equation (2) for the whole sample, for small-scale businesses sample set and large-scale businesses sample set. ***,**, * correspond to significance levels $1 \%, 5 \%$ and $10 \%$. Numbers in square brackets indicate $t$-values.

Source: The authors' estimation. 
Theoretically, according to Gentry, Vaidyanathan, and Lee (1990), Petersen and Rajan (1997), this positive influence may result from shortening the cash cycle, thus cutting transaction costs for trade payables. Research results verify that large-scale businesses still benefit from trade payables thanks to their superior market position, which helps them impose beneficial trade conditions on their suppliers. In the meantime, although the negative influences of trade payables on firm performance for small-scale businesses sample set remain questionable, these results may still be explained with the demerits of a small-scale asset holding and a weak market position, which may lead to difficulties in imposing trade conditions on suppliers, and hence, small-scale businesses may not benefit from trade payables and may even shoulder higher financing costs.

Apart from the independent variables, internal financial factors such as firm size, growth and debt ratio also affect firm performance. The impacts of economic cycles on firm performance via GDP growth are negative, especially to small-scale businesses, but are unclear to large-scale businesses.

\section{Conclusion and Policy Implications}

To examine the impacts of trade credit on firm performance of listed companies, the study was conducted with data obtained from 279 companies listed on HOSE from 2012 to 2018. The main research findings include: (1) Accounts receivable affects firm performance negatively, including small-scale businesses, but positively affects performance of large-scale businesses; (2) Trade payables impacts firm performance positively, including large-scale businesses, but their impacts on firm performance of small-scale businesses, despite negative, remain ambiguous. The reasons might be that large-scale businesses, with an easier access to funding at low costs and a superior market position to impose trade conditions on partners, may ultimately benefit from trade credit, regardless through accounts receivable or trade payables. Meanwhile, small-scale businesses under financial constraints resort to trade credit as a tool to expand market share, despite hidden costs and unfavorable trade conditions.

Research results indicate that corporates should expand their business to capitalize on the benefits of trade credit. Furthermore, small-scale businesses should be cautious with trade credit management to increase benefits and they should control the costs of trade credit. The limitation of the study lies in the fact that the impacts of trade credit on unlisted SMEs as well as the impacts of financial distress on the relationship between trade credit and firm performance have not been examined. This serves as a suggestion for future research.

\section{References:}

Abuhommous, A.a.A.A. 2017. The impact of offering trade credit on firms' profitability. Journal of Corporate Accounting \& Finance, 28(6), 29-40. 
Allen, F., Qian, J., Qian, M. 2005. Law, finance, and economic growth in China. Journal of financial economics, 77(1), 57-116.

Almeida, H., Campello, M., Weisbach, M.S. 2004. The cash flow sensitivity of cash. The Journal of Finance, 59(4), 1777-1804.

Ayyagari, M., Demirgüç-Kunt, A., Maksimovic, V. 2010. Formal versus informal finance: Evidence from China. The Review of Financial Studies, 23(8), 3048-3097.

Brennan, M.J., Maksimovics, V., Zechner, J. 1988. Vendor financing. The Journal of Finance, 43(5), 1127-1141.

Cachon, G.P., Fisher, M. 2000. Supply chain inventory management and the value of shared information. Management science, 46(8), 1032-1048.

Carbo-Valverde, S., Rodriguez-Fernandez, F., Udell, G.F. 2009. Bank market power and SME financing constraints. Review of Finance, 13(2), 309-340.

Carbo-Valverde, S., Rodriguez-Fernandez, F., Udell, G.F. 2016. Trade credit, the financial crisis, and SME access to finance. Journal of Money, Credit and Banking, 48(1).

Casey, E., O'Toole, C.M. 2014. Bank lending constraints, trade credit and alternative financing during the financial crisis: Evidence from European SMEs. Journal of Corporate Finance, 27, 173-193.

Cunat, V. 2007. Trade credit: suppliers as debt collectors and insurance providers. The Review of Financial Studies, 20(2), 491-527.

Dass, N., Kale, J.R., Nanda, V. 2015. Trade credit, relationship-specific investment, and product market power. Review of Finance, 19(5), 1867-1923.

Deloof, M. 2003. Does working capital management affect profitability of Belgian firms? Journal of business finance \& Accounting, 30(3-4), 573-588.

Demirgüç-Kunt, A., Maksimovic, V. 2001. Firms as financial intermediaries: Evidence from trade credit data (Vol. 2696). World Bank. Development Research Group, Finance.

Emery, G.W. 1987. An optimal financial response to variable demand. Journal of financial and quantitative analysis, 22(2), 209-225.

Fabbri, D., Klapper, L. 2008. Trade credit supply, market power and the matching of trade credit terms. Policy research working paper, 4754.

Ferrando, A., Mulier, K. 2013. Do firms use the trade credit channel to manage growth? Journal of Banking \& Finance, 37(8), 3035-3046.

Ferris, J.S. 1981. A transactions theory of trade credit use. The Quarterly Journal of Economics, 96(2), 243-270.

Fisman, R. 2001. Trade credit and productive efficiency in developing countries. World Development, 29(2), 311-321.

Fisman, R., Love, I. 2003. Trade credit, financial intermediary development, and industry growth. The Journal of Finance, 58(1), 353-374.

Garcia-Appendini, E., Montoriol-Garriga, J. 2013. Firms as liquidity providers: Evidence from the 2007-2008 financial crisis. Journal of financial economics, 109(1).

García-Teruel, P.J., Martinez-Solano, P. 2010. Determinants of trade credit: A comparative study of European SMEs. International Small Business Journal, 28(3), 215-233.

Gentry, J.A., Vaidyanathan, R., Lee, H.W. 1990. A weighted cash conversion cycle. Financial Management, 90-99.

Giannetti, M. 2003. Do better institutions mitigate agency problems? Evidence from corporate finance choices. Journal of financial and quantitative analysis, 38(1), 185.

Hillier, D., Ross, S., Westerfield, R., Jaffe, J., Jordan, B. 2013. Corporate finance. (2nd Ed.). McGraw Hill.

Hoang, H.C., Xiao, Q., Akbar, S. 2019. Trade credit, firm profitability, and financial constraints. International Journal of Managerial Finance. 
Huyghebaert, N. 2006. On the Determinants and dynamics of trade credit use: Empirical evidence from business Start-ups. Journal of business finance \& Accounting, 33(1-2), 305-328.

Kestens, K., Van Cauwenberge, P., Bauwhede, H.V. 2012. Trade credit and company performance during the 2008 financial crisis. Accounting \& Finance, 52(4), 1125.

Klapper, L., Laeven, L., Rajan, R. 2012. Trade credit contracts. The Review of Financial Studies, 25(3), 838-867.

Kulp, S.C. 2002. The effect of information precision and information reliability on manufacturer-retailer relationships. The Accounting Review, 77(3), 653-677.

Lee, H.H., Zhou, J., Wang, J. 2018. Trade credit financing under competition and its impact on firm performance in supply chains. Manufacturing \& Service Operations Management, 20(1), 36-52.

Long, M.S., Malitz, I.B., Ravid, S.A. 1993. Trade credit, quality guarantees, and product marketability. Financial Management, 117-127.

Love, I., Zaidi, R. 2010. Trade credit, bank credit and financial crisis. International Review of Finance, 10(1), 125-147.

Martínez-Sola, C., García-Teruel, P.J., Martínez-Solano, P. 2014. Trade credit and SME profitability. Small Business Economics, 42(3), 561-577.

Meltzer, A.H. 1960. Mercantile credit, monetary policy, and size of firms. The review of Economics and Statistics, 429-437.

Mian, S.L., Smith Jr, C.W. 1992. Accounts receivable management policy: theory and evidence. The Journal of Finance, 47(1), 169-200.

Mian, S.L., Smith Jr, C.W. 1994. Extending trade credit and financing receivables. Journal of Applied Corporate Finance, 7(1), 75-84.

Molina, C.A., Preve, L.A. 2009. Trade receivables policy of distressed firms and its effect on the costs of financial distress. Financial Management, 38(3), 663-686.

Petersen, M.A., Rajan, R.G. 1994a. The benefits of lending relationships: Evidence from small business data. The Journal of Finance, 49(1), 3-37.

Petersen, M.A., Rajan, R.G. 1994b. The effect of credit market competition on lending relationships (No. w4921). National Bureau of Economic Research.

Petersen, M.A., Rajan, R.G. 1997. Trade credit: theories and evidence. The Review of Financial Studies, 10(3), 661-691.

Pham Quoc Viet, Nguyen Huu Duy. 2017. Quan hệ giữa tín dụng thương mại và tín dụng ngân hàng: bằng chứng thực nghiệm tại Việt Nam. Tap chi tai chinh. Retrieved from http://tapchitaichinh.vn /nghien-cuu--trao-doi/trao-doi-binh-luan/quan-he-giua-tindung-thuong-mai-va-tin-dung-ngan-hang-nghien-cuu-thuc-nghiem-tai-viet-nam129840.html.

Preve, L.A., Love, I., Sarria-Allende, V. 2005. Trade credit and bank credit: Evidence from recent financial crises: The World Bank.

Sartoris, W.L., Hill, N.C. 1983. A generalized cash flow approach to short-term financial decisions. The Journal of Finance, 38(2), 349-360.

Schwartz, R.A. 1974. An economic model of trade credit. Journal of financial and quantitative analysis, 9(4), 643-657.

Van Horen, N. 2005. Trade credit as a competitiveness tool; evidence from developing countries. Evidence from Developing Countries (February). Retrieved from https://papers.ssrn.com/sol3/papers.cfm?abstract_id=562410 